\title{
SPERM OUTPUT OF RABBITS AT VARIOUS EJACULATION FREQUENCIES AND THEIR USE IN THE DESIGN OF EXPERIMENTS*
}

\author{
C. DESJARDINS $\dagger$, K. T. KIRTON $\ddagger$ AND H. D. HAFS \\ Department of Dairy, Animal Reproduction Laboratory, \\ Michigan State University, East Lansing, \\ Michigan, U.S.A.
}

(Received 8th October 1966, revised 6th December 1966)

\begin{abstract}
Summary. Each of twelve rabbits was ejaculated for 5-week periods at frequencies of: once a week $(1 \times F)$; four times on Friday $(4 \times F)$; twice on Monday, Wednesday and Friday $(2 \times \mathrm{MWF})$; and once daily except Sunday $(1 \times M-S)$. Average sperm outputs/ejaculate $\left(\times 10^{6}\right)$ for the four ejaculation frequencies were: 273 for $1 \times \mathbf{F} ; 114,207,141$ and 80 for first, second, third and fourth ejaculates, respectively, at $4 \times \mathrm{F} ; 78$ and 128 for first and second ejaculates, respectively, at $2 \times \mathrm{MWF}$; and 86 for $1 \times \mathrm{M}-\mathrm{S}$. Repetitive ejaculation significantly increased weekly sperm output $(P<0.01)$. Component of variance analysis of weekly sperm output indicated that differences among bucks were magnified by the more intensive ejaculation frequencies, but not as much as average sperm output.
\end{abstract}

\section{INTRODUCTION}

Sperm output at various ejaculation frequencies has been investigated in several domesticated animals. Unfortunately, similar data for rabbits are not extensive although this laboratory animal is well suited for the study of gonadal physiology. In the course of research utilizing sperm output of rabbits as the criterion of response, it became apparent to us that an ejaculation frequency that maximized sperm output was most likely to reveal differences between treatments imposed to alter sperm production.

The literature pertaining to sperm output in rabbits was summarized by Gregoire, Bratton \& Foote (1958). Their data indicated that daily ejaculation resulted in about four times as many spermatozoa as obtained from weekly ejaculation of an equal number of rabbits over the experimental period of 43 weeks. This experiment, as well as those conducted with other species, suggested the necessity of imposing relatively high ejaculation frequencies and possibly repetitive ejaculations to maximize sperm output.

* Published with the approval of the Director of the Michigan Agricultural Experiment Station as Journal Article No. 3934. Some of these data were published in abstract form (J.Anim. Sci. 24, 916, 1965).

$\dagger$ Present Address: The Jackson Laboratory, Hamilton Sta., Bar Harbor, Maine.

† Predoctoral Fellow, U.S.P.H.S. 
The study reported here was designed primarily to quantify sperm output of rabbits at four ejaculation frequencies. Secondly, semen volume, protein, fructose and citric acid contents were determined as parameters of accessory gland activity. A third object of this research was to estimate the error variance associated with sperm output and to use these values to indicate desirable sizes of future experiments.

\section{MATERIALS AND METHODS}

Each of twelve rabbits (nine Dutch-belted and three New Zealand; $12 \pm 2$ months of age) was ejaculated for 5-week periods at frequencies of one ejaculate/week $(1 \times \mathrm{F})$, four ejaculates on Friday $(4 \times \mathrm{F})$, two ejaculates on Monday, Wednesday and Friday $(2 \times \mathrm{MWF})$, and one ejaculate/day except Sunday $(1 \times \mathrm{M}-\mathrm{S})$. The sequence of 5 -week periods (ejaculation frequencies) was determined at random for each rabbit and a l-week adjustment period was imposed between successive ejaculation frequencies. During adjustment periods, the bucks were ejaculated at their next assigned frequency and these data were discarded.

The rabbits were housed at $18^{\circ} \mathrm{C}$ with $14 \mathrm{hr}$ of light and $10 \mathrm{hr}$ of darkness. Semen samples were obtained by the method of Gregoire et al. (1958). No attempt was made to stimulate bucks before ejaculation. Semen volume without gel-mass was determined directly from the graduated collection tube immediately after each ejaculation. An interval of about $15 \mathrm{~min}$ was interposed between consecutive collections from a rabbit on any given day. Sperm concentration was determined haemocytometrically and immediately thereafter the semen was centrifuged at $10,000 \mathrm{~g}$ for $30 \mathrm{~min}$ at $5^{\circ} \mathrm{C}$.

The supernatant seminal plasma was removed, pooled for each rabbit by day, and stored at $-20^{\circ} \mathrm{C}$. The pooled seminal plasma samples were analysed for protein by the method of Gornall, Bardawill \& David (1949) using bovine serum albumen as a reference. The same samples were analysed for fructose by the procedure of Roe (1934) and for citric acid by the method of Saffran \& Denstedt (1948).

The variances among and within bucks were estimated for weekly sperm output at each ejaculation frequency according to the methods outlined by Henderson (1960). These variances were used to estimate the number of replications (bucks and ejaculates within bucks) necessary to detect specified minimal differences between treatments at a given level of significance and with a specified probability of detecting the difference in future experiments. These computations were similar to those used previously for sperm output data for bulls (Hafs, Bratton, Henderson \& Foote, 1958).

\section{RESULTS}

\section{Sperm output}

The average values for the volume of semen, concentration of spermatozoa and spermatozoa/ejaculate are listed in Table 1. The average volume of semen for first ejaculates was not significantly affected by the four ejaculation frequencies $(P<0 \cdot 25)$ but second, third and fourth ejaculates were characterized 
by progressively smaller volumes $(P>0.01)$. The average concentration of spermatozoa in first ejaculates appeared to vary inversely with ejaculation frequency $(P<0.01)$. However, the average concentration of spermatozoa in second ejaculates was much greater than that in first ejaculates $(P<0.01)$, and even that of third and fourth ejaculates was significantly greater than the sperm concentration of first ejaculates for $4 \times \mathrm{F}(P<0.01)$. The average total spermatozoa in first ejaculates for $4 \times \mathrm{F}, 2 \times \mathrm{MWF}$ and $\mathrm{I} \times \mathrm{M}-\mathrm{S}$ was not significantly different $(P>0 \cdot 10)$. In contrast, analyses of variance revealed that second and third ejaculates contained significantly more total spermatozoa/ejaculate than did first ejaculates obtained at $4 \times \mathrm{F}(P<0.01)$.

TABLE 1

AVERAGE SEMEN VOLUME, SPERM CONGENTRATION, AND SPERM/ EJACULATE*

\begin{tabular}{|c|c|c|c|c|}
\hline \multirow[b]{2}{*}{$\begin{array}{l}\text { Ejaculation } \\
\text { frequency }\end{array}$} & \multirow[b]{2}{*}{$\begin{array}{c}\text { Ejaculate } \\
\text { number }\end{array}$} & \multirow{2}{*}{$\begin{array}{c}\text { Semen } \\
\text { volume } \\
(m l)\end{array}$} & \multicolumn{2}{|c|}{ Spermatozoa $\left(\times 10^{6}\right)$} \\
\hline & & & $\begin{array}{l}P e r \\
m l\end{array}$ & $\begin{array}{c}\text { Per } \\
\text { ejaculate }\end{array}$ \\
\hline $1 \times \mathrm{F}+$ & 1 & $0.57 \pm 0.04$ & $463 \pm 48$ & $273 \pm 51$ \\
\hline $4 \times F$ & $\begin{array}{l}1 \\
2 \\
3 \\
4\end{array}$ & $\begin{array}{l}0.51 \pm 0.05 \\
0.41 \pm 0.02 \\
0.29 \pm 0.02 \\
0.19 \pm 0.03\end{array}$ & $\begin{array}{l}285 \pm 34 \\
505 \pm 45 \\
448 \pm 52 \\
389 \pm 92\end{array}$ & $\begin{array}{r}114 \pm 15 \\
207 \pm 23 \\
141 \pm 19 \\
80 \pm 21\end{array}$ \\
\hline $2 \times M W F$ & $\begin{array}{l}1 \\
2\end{array}$ & $\begin{array}{l}0.49 \pm 0.02 \\
0.34 \pm 0.02\end{array}$ & $\begin{array}{l}168 \pm 42 \\
349 \pm 73\end{array}$ & $\begin{array}{c}78 \pm 8 \\
128 \pm 10\end{array}$ \\
\hline $1 \times M-S$ & 1 & $0.53 \pm 0.08$ & $223 \pm 44$ & $86 \pm 5$ \\
\hline
\end{tabular}

* Means \pm standard errors.

$\dagger$ See text for abbreviations.

Analysis of average weekly sperm output values (Table 2) revealed no significant differences between the average weekly sperm output on the three intensive ejaculation frequencies $(P<0 \cdot 10)$, but that each of these three averages was significantly greater than that for $1 \times \mathrm{F}(P<0 \cdot 01)$. The coefficients of variation were smallest for the intensive ejaculation frequencies, although the total error variance $\left(\hat{\sigma}_{\mathrm{b}}^{2}+\hat{\sigma}_{\mathrm{w}: \mathrm{b}}^{2}\right.$ Table 2$)$ was simultaneously larger. The increased

TABLE 2

AVERAGE WEEKLY SPERM OUTPUT $\left(\times 10^{6}\right)$, AND ASSOCIATED COMPONENTS OF VARIANGE AND COEFFIGIENTS OF VARIATION

\begin{tabular}{|c|c|c|c|c|}
\hline \multirow{2}{*}{$\begin{array}{l}\text { Ejaculation } \\
\text { frequency }\end{array}$} & \multirow{2}{*}{$\begin{array}{c}\text { Sperm/week } \\
(\bar{x} \pm S E)\end{array}$} & \multicolumn{2}{|c|}{ Components of variance* } & \multirow[b]{2}{*}{ C.V. $\dagger$} \\
\hline & & $\hat{\sigma}_{b}^{2}$ & $\hat{\sigma}_{w: b}^{2}$ & \\
\hline $1 \times F \ddagger$ & $273 \pm 51$ & $23 \quad(35)$ & $42 \quad(65)$ & 0.93 \\
\hline $4 \times F$ & $543 \pm 86$ & $71(44)$ & $89 \quad(56)$ & 0.73 \\
\hline $2 \times \mathrm{MWF}$ & $619 \pm 103$ & $113(61)$ & 71 (39) & 0.69 \\
\hline $1 \times \mathrm{M}-\mathrm{S}$ & $519 \pm 73$ & 56 & $43 \quad(43)$ & 0.61 \\
\hline
\end{tabular}

* $\hat{\sigma}_{b}^{2}$ (buck variance) and $\hat{\sigma}_{w: b}^{2}$ (weeks within buck variance) each in thousands; percentage of total variance in parentheses.

$\dagger$ Coefficient of variation.

$\ddagger$ See text for abbreviations. 
total error variance associated with the intensive ejaculation frequencies was chiefly due to increased variance among bucks $\left(\hat{\sigma}_{b}^{2}\right)$. The absolute magnitude of $\hat{\sigma}_{\mathrm{w}: \mathrm{b}}^{2}$ was greatest on the two ejaculation frequencies which involved repeated ejaculation but the relative magnitude was greatest at $1 \times F$.

The data for the $2 \times \mathrm{MWF}$ and $\mathrm{I} \times \mathrm{M}-\mathrm{S}$ ejaculation frequencies were studied in separate analyses of variance to determine whether sperm output on Mondays was greater than for the other ejaculation days. Although the sperm output averaged $15 \%$ more on Mondays than on the other days on $2 \times \mathrm{MWF}$ and $1 \times \mathrm{M}-\mathrm{S}$, these differences did not approach significance $(P>0 \cdot 25)$ and consequently they were ignored in the component of variance analyses. Nevertheless, the error variances for $2 \times \mathrm{MWF}$ and $\mathrm{l} \times \mathrm{M}-\mathrm{S}$ were probably exaggerated by the unequal intervals between ejaculation days.

\section{Semen protein, fructose and citric acid}

The average semen contents of protein, fructose and citric acid/ejaculate from each ejaculation frequency are summarized in Table 3. First ejaculates from the four ejaculation frequencies did not differ significantly in their content of these three constituents $(P>0 \cdot 25)$, but each consecutive ejaculate contained less of each constituent than its predecessor $(P<0.05)$. In this regard, the values shown in Table 3 appeared to parallel semen volume (Table 1). Average weekly outputs of protein, fructose and citric acid at the $2 \times \mathrm{MWF}$ and $1 \times \mathrm{M}-\mathrm{S}$

TABLE 3

AVERAGE SEMINAL PROTEIN, FRUCTOSE, AND CITRIG AGID*

\begin{tabular}{|c|c|c|c|c|}
\hline $\begin{array}{l}\text { Ejaculation } \\
\text { frequency }\end{array}$ & $\begin{array}{c}\text { Ejaculate } \\
\text { number }\end{array}$ & Protein & Fructose & Citric acid \\
\hline $1 \times \mathrm{F} \dagger$ & 1 & $35 \cdot 2$ & $1 \cdot 20$ & $1 \cdot 54$ \\
\hline $4 \times F$ & $\begin{array}{l}1 \\
2 \\
3 \\
4\end{array}$ & $\begin{array}{r}36 \cdot 7 \\
27 \cdot 2 \\
17 \cdot 6 \\
5.7\end{array}$ & $\begin{array}{l}1.44 \\
0.92 \\
0.65 \\
0.16\end{array}$ & $\begin{array}{l}1.02 \\
0.76 \\
0.48 \\
0 \cdot 19\end{array}$ \\
\hline $2 \times \mathbf{M W F}$ & $\begin{array}{l}1 \\
2\end{array}$ & $\begin{array}{l}34 \cdot 3 \\
20 \cdot 0\end{array}$ & $\begin{array}{l}1 \cdot 16 \\
0.77\end{array}$ & $\begin{array}{l}1 \cdot 05 \\
0.62\end{array}$ \\
\hline $1 \times M-S$ & 1 & $27 \cdot 4$ & $1 \cdot 12$ & $1 \cdot 08$ \\
\hline
\end{tabular}

* Mg/ejaculate.

$\dagger$ See text for abbreviations.

ejaculation frequencies did not differ for any of these three constituents $(P>$ $0.25)$, but were significantly greater $(P<0.01)$ than those obtained with the $1 \times \mathrm{F}$ or $4 \times \mathrm{F}$ ejaculation frequencies.

\section{Power of test in future experiments}

The power values $\left(1-\mathrm{P}_{\mathrm{II}}\right)$ of some possible future experiments with varying numbers of bucks/treatment and weeks/buck (Table 4) were calculated from the variances for $2 \times \mathrm{MWF}$, because this frequency resulted in the greatest weekly sperm output. The data in Table 4 indicated, for example, that an experimental design in which bucks are nested within treatments would require about twenty bucks for each treatment and at least 5 weeks of ejaculation to 
provide a $75 \%$ chance of detecting a $50 \%$ treatment difference at the $5 \%$ level of significance. In contrast, a reversal design in which bucks are factorially related to treatments would require that each of a total of only ten bucks be ejaculated for 5 weeks on each treatment to provide a $77 \%$ chance of detecting a $25 \%$ treatment difference at the $5 \%$ level of significance.

TABLE 4

PERCENTAGE GHANCE OF DETEGTING A TREATMENT DIFFERENCE OF $50 \%$ OR $25 \%$ OF MEAN WEEKLY SPERM OUTPUT AT THE $5 \%$ LEVEL OF SIGNIFIGANCE WITH VARYING NUMBERS OF BUCKS/ TREATMENT AND WEEKS/BUCK

\begin{tabular}{|c|c|c|c|c|c|c|}
\hline \multirow{2}{*}{ Design } & \multirow{2}{*}{$\begin{array}{c}\text { Percentage } \\
\text { difference } \\
\text { detected }\end{array}$} & \multirow{2}{*}{$\begin{array}{l}\text { No. of } \\
\text { bucks* }\end{array}$} & \multicolumn{4}{|c|}{ No. of weeks/buck } \\
\hline & & & 1 & 5 & 10 & 20 \\
\hline Nested & 50 & $\begin{array}{r}5 \\
10 \\
20\end{array}$ & $\begin{array}{r}<24 \\
34 \\
59\end{array}$ & $\begin{array}{r}<24 \\
45 \\
75\end{array}$ & $\begin{array}{r}<24 \\
47 \\
78\end{array}$ & $\begin{array}{l}25 \\
49 \\
80\end{array}$ \\
\hline \multirow[t]{2}{*}{ Reversal } & 50 & $\begin{array}{r}5 \\
10 \\
20\end{array}$ & $\begin{array}{l}37 \\
69 \\
94\end{array}$ & $\begin{array}{r}95 \\
>99 \\
>99\end{array}$ & $\begin{array}{l}>99 \\
>99 \\
>99\end{array}$ & $\begin{array}{l}>99 \\
>99 \\
>99\end{array}$ \\
\hline & 25 & $\begin{array}{r}5 \\
10 \\
20\end{array}$ & $\begin{array}{r}<24 \\
<24 \\
43\end{array}$ & $\begin{array}{l}44 \\
77 \\
97\end{array}$ & $\begin{array}{r}71 \\
97 \\
>99\end{array}$ & $\begin{array}{r}94 \\
99 \\
>99\end{array}$ \\
\hline
\end{tabular}

* The number of bucks shown would be required for each treatment of the nested design, but represent the total in the experiment for the reversal design.

\section{DISCUSSION}

Although they provided no more total ejaculates than $1 \times \mathrm{M}-\mathrm{S}$, the weekly sperm output was greatest at ejaculation frequencies of $4 \times \mathrm{F}$ and $2 \times \mathrm{MWF}$ due to greater sperm output in second, third and fourth ejaculates than in first ejaculates. These observations suggested that the first ejaculation provided stimulation for added sperm output in subsequent ejaculates taken that day. They also suggested that more frequent multiple ejaculation frequencies such as two ejaculates daily or four ejaculates taken on each of 2 days each week may result in higher weekly sperm output than the frequencies considered here.

The present observations are reminiscent of similar data reported by Branton, D'Arensbourg \& Johnston (1952), who observed that first ejaculates taken from bulls without sexual preparation contained fewer total spermatozoa than did second ejaculates. However, when the bulls were stimulated before ejaculation, first ejaculates contained more spermatozoa than second ejaculates. The results of the present experiment could be interpreted to suggest that rabbits may also respond to pre-ejaculatory stimulation with increased sperm output.

While this manuscript was in preparation, Amann (1966) published sperm output data similar to those reported here. When the values for weekly sperm output in Table 2 were adjusted for sperm losses in the artificial vaginae (Bredderman, Foote \& Yassen, 1964) the sperm output data in the present paper were found to be remarkably similar to those reported by Amann. On the basis of 125 observations, an average of $10 \%$ of the ejaculated sperm were found adhering to the artificial vagina in the present study. 
Semen volume was greatest in first ejaculates and declined in each successive ejaculate. However, average semen volume of first ejaculates taken at the four ejaculation frequencies did not differ appreciably. Consequently, weekly semen volume was greatest with $1 \times \mathrm{M}-\mathrm{S}$, the frequency that provided the most first ejaculates. These comparisons indicated that the secretions of the accessory glands were probably fully replenished within the $24 \mathrm{hr}$ which elapsed between $1 \times \mathrm{M}-\mathrm{S}$ ejaculations, but not within the $15 \mathrm{~min}$ which elapsed between repeat ejaculations. To the extent that semen protein, fructose and citric acid measure the contributions of different accessory glands, the data suggested that more than one of the accessory glands required in excess of $15 \mathrm{~min}$ to replenish their secretions because the decline in semen volume with repeat ejaculation was associated with similar declines in protein as well as in fructose and citric acid.

The analyses of components of variance revealed that sperm output differences among bucks were more evident at intensive ejaculation frequencies than at $\mathrm{I} \times \mathrm{F}$ and suggested that experiments using intensive ejaculation frequencies may be more sensitive in the detection of treatment differences in sperm production as reflected by sperm output.

Calculations of the power of some possible future experiments revealed some of the hazards of small experiments. They also revealed that, in comparison with the situation when it is necessary to use each buck on only one treatment, fewer bucks are required to achieve any given Type II error when bucks can be arranged factorially to treatments in a reversal trial. Unfortunately, when treatment effects are terminal or persistent the reversal design may be unsatisfactory. Furthermore, the total time required to complete an experiment with a reversal design relative to the time required for an experiment with a nested design would be a multiple of the number of treatments.

\section{ACKNOWLEDGMENTS}

K. L. Macmillan and Helga Hulkonen provided valuable assistance in several phases of this research.

\section{REFERENCES}

Amann, R. P. (1966) Effect of ejaculation frequency and breed on semen characteristics and sperm output of rabbits. F. Reprod. Fert. 11, 291.

Branton, C., D'Arensbourg, G. \& Johnston, J. E. (1952) Semen production, fructose content of semen and fertility of dairy bulls as related to sexual excitement. F. Dairy Sci. 35, 801.

Bredderman, P. J., Foote, R. H. \& Yassen, A. M. (1964) An improved artificial vagina for collecting rabbit semen. 7. Reprod. Fert. 7, 401.

Gornall, A. G., Bardawill, C. J. \& David, M. M. (1949) Determination of serum proteins by means of the biuret reaction. 7 . biol. Chem. 177, 751 .

Gregorre, A. T., Bratton, R. W. \& Foote, R. H. (1958) Sperm output and fertility of rabbits ejaculated either once a week or once a day for forty-three weeks. F. Anim. Sci. 17, 243.

Hafs, H. D., Bratton, R. W., Henderson, G. R. \& Foote, R. H. (1958) Estimation of some variance components of bovine semen criteria and their use in the design of experiments. F. Dairy Sci. 51, 96.

Henderson, C. R. (1960) Design and analysis of animal husbandry experiments. In: Techniques and Procedures in Animal Production Research, p. 1. Q Corporation, Albany 10, New York.

RoE, J. H. (1934) A colorimetric method for the determination of fructose in blood and urine. F. biol. Chem. 107, 15.

Saffran, M. \& Denstedt, O. F. (1948) A rapid method for the determination of citric acid. F. biol. Chem. 175, 849 . 